\title{
YÜKSEK MUKAVEMETLİ ÇELIKLERDE LAZER KAYNAĞI UYGULAMALARI
}

\author{
Tuncay ALPAR \\ Oktay ÇELENK \\ Kadir ÇAVDAR
}

Alınma: 02.07.2021; düzeltme: 09.11.2021; kabul: 10.11.2021

Öz: Lazer uygulamaları, gün geçtikçe kullanımı yaygınlaşan, mühendislikten tıbba kadar geniş yelpazede kendine yer bulan, yüksek teknoloji içeren işlemlerdir. Metal endüstrisinde ise lazer; kesme, yüzey işleme, sertleştirme, kaplama ve kaynak işlemlerinde sıklıkla kullanılmaktadır. Bu çalışmada, lazer kaynağının diğer kaynak türlerine göre önemli avantajlarını ortaya koymak için literatürdeki mevcut çalışmalar incelenmiş ve analiz edilmiştir.

Günümüzde otomotiv sanayi için büyük önem arz eden yüksek mukavemetli çeliklerin birleştirilmesi işleminde lazer kaynağı kullanılmaktadır. Yüksek mukavemetli çeliklerin birleştirme işlemi esnasında yaşanan bazı sorunlar vardır ve bu sorunları gidermek için lazer kaynak parametrelerinin optimizasyonu oldukça önemlidir. Bu çalışmada, önceki araştırmacıların yapmış olduğu yüksek mukavemetli çeliklerin kaynak işleminde işlem parametreleri, işlemde oluşan kusurlar, içyapilar, deneysel çalışmalar irdelenmiş̧ir.

Anahtar Kelimeler: Lazer, Lazer Kaynağı, Yüksek Mukavemetli Çelikler, Isı Tesiri Altındaki Bölge, Kaynak Parametreleri

\section{Laser Welding Applications on High Strength Steels}

\begin{abstract}
Laser applications are high-tech processes that are becoming widespread day by day and find a place in a wide range from engineering to medicine. Laser in metal industry; It is frequently used in cutting, surface treatment, hardening, coating and welding processes. In this study, in order to reveal the important advantages of laser welding over other welding types, published researchs in the literature have been examined and analyzed.

Laser welding is used in the assembly of high strength steels, which are of great importance for the automotive industry today. There are some problems experienced during the joining process of high strength steels and optimization of laser welding parameters is very important to solve these problems. In this study, the process parameters in the welding process of the high strength steels made by the previous researchers, the defects in the process, microstructure of material, and experimental studies are reviewed.
\end{abstract}

Keywords: Laser, Laser Welding, High Strength Steels, Heat Affected Zone, Welding Parameters

\footnotetext{
Bursa Uludağ Üniversitesi Fen Bilimleri Enstitüsü, Makine Mühendisliği ABD., 16059, Nilüfer, Bursa, (Durmazlar Makine A.Ş. TÜBİTAK 2244 Doktora Programı)

** Durmazlar Makine A.Ş.

**** Bursa Uludağ Üniversitesi Mühendislik Fakültesi, Makine Mühendisliği Bölümü, 16059, Nilüfer, Bursa İletişim Yazarı: Tuncay Alpar (tuncayalpar4848@gmail.com)
} 


\section{GİRIŞ}

Günümüzde uygulanan belirli çevre normları sebebiyle, otomotiv üreticileri ürettikleri araçların emisyon değerlerini minimuma indirme çabası içerisindedir (Rossini ve diğ., 2015). Bunu da araçları hafifletme yoluyla sağlamaya çalışmaktadırlar. Hafifletme işlemi aracın rijitliğini ve çarpışma dayanımını azaltmadan yapılmalıdır. Otomotiv üreticileri, istenen özellikleri sağlamak için araçlarda hayati öneme sahip parçaları (şase, sütunlar vb.), dayanım/ağırlık oranı çok iyi düzeyde olan ileri yüksek mukavemetli çelikleri kullanmaktadırlar. İleri yüksek mukavemetli çeliklerin bu özellikleri sayesinde hem düşük yakıt tüketimi ve çevreye daha az zararlı gaz salınımı sağlanmakta, hem de yolcu güvenliğinden ödün verilmemektedir. Aynı zamanda aracın hafif olması performans artışı anlamına gelmektedir (Kim ve diğ., 2010, Agarwal ve diğ., 2018). İleri yüksek mukavemetli çelikler, bu özellikleri ve iyi şekillendirilebilir olması sebebiyle geleneksel çeliklerin yerini almıştır. Çift fazlı çelikler (DP), kompleks fazlı çelikler (CP), martenzitik çelikler (MART) ve deformasyonla sertleşen çelikler (TRIP), arayer atomsuz çelikler (IF), firında sertleşebilen çelikler (BH), düşük alaşımlı yüksek mukavemetli çelikler (HSLA) otomotivde en yaygın kullanılan çeliklerdir (Yüce ve diğ., 2016, Evin ve Tomas, 2017). Tüm bu çelikler içinde, yüksek mukavemet özellikleri ve iyi şekil verilebilme kabiliyetinden dolayı en kullanışlı grup DP çelikleridir. DP çelikleri ferritik/martenzitik yapıda olup yumuşak/sünek ferrit yapısı içinde dağılmış sert martenzit fazını içermektedir (Rashid, 1981).

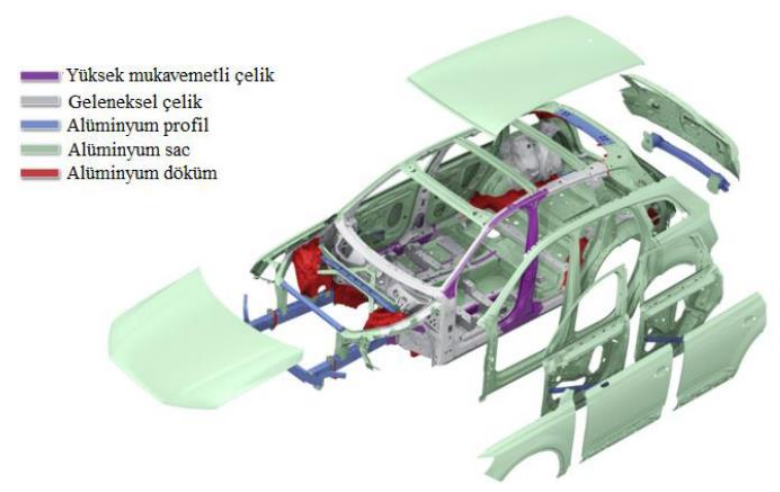

Sekil 1:

Araçlarda kullanılan malzemeler ve kullanım yerleri (Huetter,2015)

Kaynak işlemi, otomotiv üretiminde komponentleri birleştirmek için sıkça kullanılan yöntemdir. Kolay otomasyon, yüksek kaynak hızları, yüksek güç yoğunluğu, dar 1sı tesiri altında bölge (ITAB), yüksek kaynak dikiş derinliği ve düşük termal çarpılmalara yol açtığı için lazer kaynağı kullanımının popülaritesi son yıllarda oldukça artmıştır (Tunçel ve diğ., 2020a). Lazer teknolojileri ve lazer kaynağı; yüksek hassasiyet, yüksek verimlilik, esneklik, otomasyona uygunluk gibi endüstriyel uygulamalara açık avantajlarından dolayı yeni bir teknolojik çağ başlatmıştır (Iordachescu ve diğ., 2011). Lazer 1şını yoğunlaştırılmış 1sı kaynağıdır ve kaynağın derin ve dar bir bölgede olmasına imkân tanır (Behera, 2020). Bu sayede kaynak için gereken enerji miktarı azalmakta, kaynak hızı yükselmekte ve malzemenin birleşme bölgesi dışındaki bölgelere gereksiz 1sıl yük uygulanmamaktadır. Bu da malzemelerde mekanik özelliklerin korunmasını ve düzgün kaynak dikişi oluşumunu sağlamaktadır (Püskülcü ve Koçlular, 2009). Araçlarda kullanılan metaller tek çeşit değildir ve bu farklı malzemelerin kaynak edilmesinde birtakım zorluklar mevcuttur. Malzemeler farklı metalurjik, termal ve fiziksel özelliklere sahip olduğundan, farklı malzemelerin kaynağı aynı iki malzemeyi kaynak etmekten daha zordur 
(Yüce ve diğ., 2016). Literatürde lazer kaynak yöntemi ile uygun parametreler tespit edilerek farklı malzemelerin de başarılı şekilde kaynak edilebildiği gösterilmiştir. Kaynak sonrası oluşan mikroyapının, kaynak edilen parçaların sertlik, çekme dayanımı gibi mekanik özellikleri üzerinde önemli etkisi vardır. $\mathrm{Bu}$ özellikleri kontrol edebilmenin yolu da çalışmalarda gösterildiği gibi ideal parametrelerin tayini ile mümkündür. Bu çalışmada, literatürde mevcut güncel araştırmalar incelenecek, lazer kaynağı uygulamasında önemli parametreler ve bu parametrelerin kaynak kalitesi üzerine etkileri analiz edilecektir.

Tablo 1. Makale Konusuna Göre Çalışmalar

\begin{tabular}{|c|c|}
\hline Makale Konusu & Alanda Çalışanlar \\
\hline $\begin{array}{l}\text { Lazer Kaynağında Güç } \\
\text { Değişimi }\end{array}$ & $\begin{array}{l}\text { Fernandes ve diğ. (2017), Uzun ve Keleş (2012), Kökey ve diğ. (2016), Wang ve diğ. } \\
\text { (2021), Taşk1n ve Çaligülü (2009), Tunçel ve diğ. (2019), Çakmakkaya ve diğ. } \\
\text { (2020), Anawa ve Olabi (2008), Wang ve diğ. (2017), Lakshminarayana ve diğ. } \\
\text { (2018), Khan ve diğ. (2011), Benyounis ve diğ. (2007), Öztürk ve diğ. (2019) }\end{array}$ \\
\hline $\begin{array}{l}\text { Lazer Kaynağında } \\
\text { İlerleme Hızı }\end{array}$ & 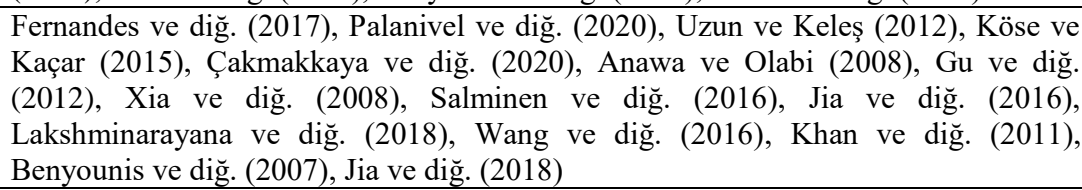 \\
\hline $\begin{array}{l}\text { Lazer Kaynağında Lazer } \\
\text { Türü }\end{array}$ & $\begin{array}{l}\text { Tunçel ve diğ. (2019), Tunçel ve diğ. (2020b), Tunçel ve diğ. (2018), Hazretinezhad } \\
\text { ve diğ. (2012), İndhu ve diğ. (2018), Xue ve diğ. (2017) }\end{array}$ \\
\hline $\begin{array}{l}\text { Lazer Kaynağında Odak } \\
\text { Mesafesi, Işın Çapı, Odak } \\
\text { Noktası }\end{array}$ & $\begin{array}{l}\text { Püskülcü ve Koçlular (2009), Behera (2020), Saravanan ve diğ. (2021), Anawa ve } \\
\text { Olabi (2008), Salminen ve diğ. (2016), Khan ve diğ. (2011), Benyounis ve diğ. } \\
\text { (2007) }\end{array}$ \\
\hline $\begin{array}{l}\text { Lazer Kaynağında Isıl } \\
\text { İşlem Uygulaması }\end{array}$ & Fernandes ve diğ. (2017), Ferreira ve diğ. (2020) \\
\hline
\end{tabular}

\section{LAZER KAYNAĞI}

Temel olarak iki tip lazer kaynağı vardır. Bunlar lazer nüfuziyet kaynağı ve lazer nokta kaynağıdır. Lazer nüfuziyet kaynağında lazer ışınının kaynak yapılacak iki malzemeyi delerek geçmesi amaçlanmaktadır. Nüfuziyet kaynağında çok yüksek güç yoğunluğundaki lazer 1şını metal malzemenin ani şekilde buharlaşmasıyla anahtar deliği (keyhole) adı verilen malzemeyi boydan boya geçen bir deliğin oluşmasını sağlar. Deliğin içinde buharlaşan metal malzemenin yarattığı plazma tarafında emilen lazer ışını duvarlarına aktarılır, duvar malzemesinin erimesi sağlanır. Eriyen malzeme sonrasında soğur ve soğuyup donan malzeme karışımı ile bu iki malzemenin birleşmesini sağlar. Lazer gücüne ve lazer ışınının özelliğine bağlı olarak $50 \mathrm{~mm}$ kalınlığa kadar birleşme sağlanabilmektedir. Ancak genellikle endüstride $20 \mathrm{~mm}$ civarlarında kalmaktadır (Püskülcü ve Koçlular, 2009).

Temel olarak lazer çalışma prensibi, aktif maddeyi 1şık veya elektrik ile uyararak atomun son yörüngesindeki elektronunun bir üst yörüngeye çıkarılması ve kararsız haldeki elektronun eski katmanına dönerken salınan foton ile lazer ışınının üretilmesine dayanır (Herd ve diğ., 1997). Endüstride sıklıkla kullanılan çeşitleri katı hal ve gaz lazerleridir. Katı hal lazerlerinde aktif ortam katı maddedir. Kaynak işleminde en yaygın kullanılan katı hal lazerleri fiber lazer ve Nd:YAG lazeridir. Gaz lazerine örnek olarak da sıkça kullanılan $\mathrm{CO}_{2}$ lazeri gösterilebilir. $\mathrm{CO}_{2}$ lazerinin çalışma mekanizması diğer lazerlerle aynıdır. Aktif ortamda (medyum) kullanılan maddenin çeşidine göre de üretilen 1şının dalga boyu, frekansı ve enerji değeri değişir.

Lazerler ayrıca atımlı (darbeli) ve sürekli dalga şeklinde de iki grupta sınıflanır. Genellikle Nd:YAG (neodyum katkı1ı itriyum alüminyum garnet) lazerler kaynak işlemlerinde atımlı 
olarak kullanılırken, $\mathrm{CO}_{2}$ lazer ve fiber lazerler sürekli dalga olarak kullanılmaktadır. Fiber lazerler, kullanılan yazılımla gerektiğinde sürekli ya da atımlı modda çalışabilmektedir. Atımlı lazerlerde atım süresi, atım frekansı gibi ek parametreler de devreye girmektedir.

Araştırmacılar, lazer kaynak işlemi esnasında 1sı girdisinin kaynak dikişi ve kaynak bölgesinde önemli değişimlere yol açabileceğini belirtmişlerdir. Kaynak yapılan bölge kendi içinde ergime bölgesi (EB), 1sı tesiri altındaki bölge (ITAB) ve temel metal (TM) olmak üzere alt bölümlere ayrılmıştır. Bu bölgeler Şekil 2'de gösterilmiştir. Detaylı olarak incelendiğinde, ITAB'ın kendi içinde de 3 bölgeye ayrıldığı görülmüştür. Bu bölgelere ergime bölgesinden ana metale doğru; TM tarafı ITAB (subkritik), EB tarafı ITAB (superkritik) ve bu iki bölge arası geçiş bölgesi ITAB (interkritik) isimlerini vermişler ve buradaki mekanik özelliklerin ve mikroyapıların farklı olduğunu göstermişlerdir.

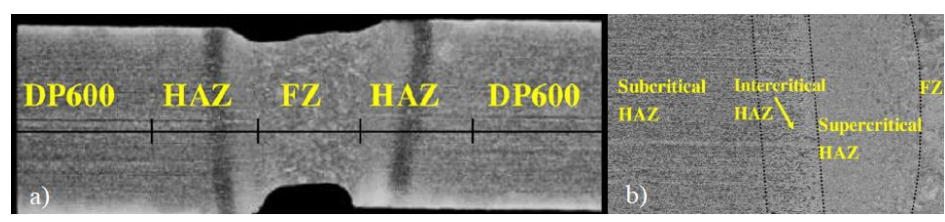

Şekil 2:

DP600 çeliğinde kaynak sırasında oluşan bölgeler a) Genel görünüm b) Detay görünüm FZ: ergime bölgesi, HAZ: ısı tesiri altındaki bölge, DP600: ana metal (Jia vd.,2016)

\section{LAZER KAYNAK PARAMETRELERI}

Malzemelerin kaynak ile birleştirilmesi işleminde parametreler oldukça önemlidir. Isı girdisi ve isıdan etkilenen bölgeler bu parametreler sonucu değişkenlik gösterir ve kaynaklı parçaların içyapısını ve mekanik özelliklerini etkiler. Lazer kaynağının en büyük avantajı burada ortaya çıkar. Parametrelerin kontrolü lazer kaynağında oldukça kolaydır. Lazer ışın gücü, kaynak ilerleme hızı, 1şın çapı, odak noktası gibi parametreler kolaylıkla CNC yardımıyla hassas şekilde değiştirilerek 1sı girdisi ve ITAB genişliği kontrol edilebilir. Bu parametreleri değiştirerek yapılan çalışmalarda başarılı sonuçlar elde edilmiştir.

\subsection{Lazer Gücü}

Endüstride kaynak işleminde $1 \mathrm{~kW}$ 'tan $10 \mathrm{~kW}$ 'a kadar lazer güç kaynakları kullanılmaktadır. Literatürde lazer gücünün yüksek mukavemetli çeliklerde kaynak numuneleri üzerine etkilerini inceleyen birçok inceleme mevcuttur. Mevcut çalışmalarda lazer gücünün birleştirilen numuneler üzerindeki ITAB ve EB özellikleri tespit edilmiş ve ideal güç değeri çalış1lan malzemeler için belirlenmiştir. Çalışmalarda ortak görüş olarak lazer gücünün kaynak kalitesi, mekanik özellikler ve içyapıya etki eden oldukça önemli bir parametre olduğu belirtilmiştir.

Fernandes ve diğ. (2017) DP600 çeliklerine darbeli Nd:YAG lazeri ile kaynak işlemi uygulamış, başlangıçta sadece güç girdisini değiştirerek ve diğer parametreleri sabit tutarak ideal güç değerini bulmuş, sonrasında atım değerlerini ve kaynak hızını değiştirerek optimal parametreleri elde etmişlerdir. Çalışmada $0,3 \mathrm{~kW}$ ortalama, $12 \mathrm{~kW}$ tepe güç değerli kaynak cihazı kullanılmıştır. \%45 lazer gücü kaynak alt ve üst kısmında sorun yaratmış, \%35 lazer gücünün uygun olduğu ifade edilmiştir. Bu parametreler ile tam birleşme sağlanmıştır. Yine de güç azaltmayla kaynak dikişi gerilimleri giderilememiş diğer parametreleri değiştirerek azaltılmaya çalışılmıştır. Lakshminarayana ve diğ. (2018) DP600 çeliklerini, kaynak hızı ve lazer gücü değerlerini değiştirerek kaynak etmişlerdir. 1,5-3,0 $\mathrm{kW}$ ve 2-4-6 m/dk değerleriyle gerçekleştirilen deneylerde $1,5 \mathrm{~kW}$ için sadece $2 \mathrm{~m} / \mathrm{dk}$ hızda tam birleşme sağlanmış, daha 
yüksek hızlarda birleşmede eksiklik görülmüştür. $3 \mathrm{~kW}$ için tüm hızlarda tam birleşme sağlanmıştır. Tunçel ve diğ. (2019) 1 mm kalınlığında DP600-DP1000 farklı malzemelerini ortalama gücü $0,3 \mathrm{~kW}$ olan darbeli $\mathrm{Nd}: Y A G$ lazer kaynak ile birleștirmiș ve mekanik özelliklerini incelemişlerdir. Lazer gücü \%20-\%75 aralığında değiştirilerek kullanılmıştır. Lazer gücündeki artışın çekme mukavemetinde artış sağladığı görülmüştür. En başarılı sonuçlar \%65\%75 güç aralığında elde edilmiştir. En iyi uzama değerleri de bu aralıkta görülmüştür. Lazer gücünün \%20'den \%75'e çıkarılması çekme dayanımını 204,25 MPa'dan 610,8 MPa'a çıkartmıştır. Aynı zamanda yükssek güçlerde daha iyi kalitede kaynak dikişi elde edilmiştir. Bu durumun sebebi yüksek 1s1 girdisi sayesinde yüksek birleşme olarak gösterilmiştir. Wang ve diğ. (2017) 1,5 mm kalınlığında DP780 çeliklerini, lazer gücünü değiştirerek, farklı 1sı girdileriyle kaynak etmiş. 0,5-5,5 kW aralığında yapılan deneylerde en düşük güç hariç diğer güçlerde tam birleşme sağlanmış $2,5 \mathrm{~kW}$ ve $3,5 \mathrm{~kW}$ değerlerinde en iyi mekanik özellikler elde etmişlerdir. $\mathrm{Bu}$ değerler sabit hız ile $(5 \mathrm{~m} / \mathrm{dk})$ is1 girdisi olarak $6,18,24,30,42,66 \mathrm{~J} / \mathrm{mm}$ olarak ifade edilmiştir. 30-42 J/mm aralığında ideal dikiş genişliği ve sertlik dağılımı elde edilmiştir. $6 \mathrm{~J} / \mathrm{mm}$ girdisinde $656 \mathrm{MPa}$ akma dayanımı ve \%6,30 uzama mevcutken, $42 \mathrm{~J} / \mathrm{mm}$ değerinde $890 \mathrm{MPa}$ akma dayanımı, \%20 uzama göstermiştir. Çakmakkaya ve diğ. (2020) St6222 ve DP600 ince saclarını $\mathrm{C}_{2}$ lazer kaynağı ile birleştirmiş, 38-47-56 kW lazer gücü, 120-180-240 m/dk hızlarda çalışmışlardır. İdeal güç ve hız değerlerini $47 \mathrm{~kW}$ ve $180 \mathrm{~m} / \mathrm{dk}$ olarak ifade etmişlerdir. Artan lazer gücünün birleşme derinliğini arttırdığını ve nüfuziyet üzerinde gücün hıza göre daha önemli parametre olduğunu belirtmişlerdir. Ayrıca yüksek güç ile yapılan kaynak işleminde sertlik değerlerinin daha yüksek olduğu gözlenmiştir. Öztürk ve diğ. (2019) 1,8 mm kalınlığındaki DP600 ve 1,5 mm kalınlığındaki DP800 çift fazlı çelik sacları CO2 lazer kaynağı ile birleştirmişlerdir. 2-3 kW güç ve 3-4 m/dk kaynak hızlarında çalışılmıştır. Kaynak edilen sacların akma ve maksimum çekme mukavemetlerinin lazer gücünün $3 \mathrm{~kW}$ ve kaynak hızının 4 $\mathrm{m} / \mathrm{dk}$ olduğu kaynak parametrelerinde daha yüksek çıktığ 1 görülmüştür. Çalışmada sac kalınlığının azaltılması ile mukavemet değerlerinden ödün vermeden şekillendirilmiş parçaların ağırlıklarının azaltılabileceği gösterilmiştir. Khan ve diğ. (2011), 0,55 mm kalınlığında martenzitik AISI 416 ve AISI 440 paslanmaz çelikler kullanmış, lazer kaynak işlem parametrelerinin ideal değerleri hedeflemişlerdir. Üç seviye lazer gücü ve kaynak hızı, iki seviye fiber çap1 olmak üzere 18 deneyden oluşan düzenek hazırlamışlardır. 0,8-0,84 kW

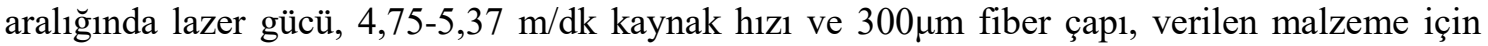
kaynak parametresinin en uygun değerleri olduğu belirtilmiştir. Kökey ve diğ. (2016) darbeli lazer ile yaptıkları çalışmada, $0,05-0,2-0,4 \mathrm{~kW}$ güç değerleri ve 06,-0,7 $\mathrm{mm} 1$ şın çapıyla çalışmış, AISI 430 paslanmaz çelik kaynağında artan lazer gücünün mukavemeti arttırdığını göstermişlerdir. $0,4 \mathrm{~kW}$ güç ve $0,7 \mathrm{~mm}$ 1şı çapı ile 12 Joule enerji değerinde çekme testinde numuneler TM'den kopmuş, düşük enerji değerlerinde kopmalar kaynak bölgesinden gerçekleşmiştir. Taşkın ve Çalıgülü (2009) AISI430/1010 çelik çiftinin lazer kaynağında güç etkisini incelemişlerdir. 2-2,25-2,5 $\mathrm{kW}$ güçlerde $1 \mathrm{~m} / \mathrm{dk}$ sabit hızda kaynak işlemi gerçekleşmişlerdir. $2,25 \mathrm{~kW}$ güç, $1 \mathrm{~m} / \mathrm{dk}$ hız değerinde ve helyum atmosferinde metalürjik açıdan en yüksek kalitede birleşme sağlandığı görülmüştür. Çekme deneyinde de en yüksek değerler helyum atmosferinde $2,25 \mathrm{~kW}$ güç ile yapılan deneyde elde edilmiştir. Tüm deneylerde helyum gazı, argon gazı kullanılan deneylere göre daha iyi sonuç vermiştir. Wang ve diğ. (2021) 20 mm kalınlığında düşük alaşımlı yüksek mukavemetli çeliklerin kaynağında 2-8 kW aralığında lazer güçleriyle çalışmış, lazer gücünün birleşmede belirleyici olduğunu, düşük güç ve düşük kaynak hızı ile yeterli birleşme sağlanamadığını göstermiş, yetersiz lazer gücünün yapıda kusurlara neden olacağını belirtmiş̧lerdir. Anawa ve Olabi (2008) ferritik östenitik çelikler için maksimum çekme dayanımı açısından deneyler gerçekleştirmiş, üretimi arttırmak ve maliyeti düşürmek adına en iyi birleşme, güç ve kaynak hızı parametrelerini bulmayı hedeflemişlerdir. Sonuçlar üzerinde en etkili faktörün lazer gücü olduğu gösterilmiştir. Yüksek güçte daha iyi birleşme sağlanmıştır. En iyi çekme dayanımı değerleri $1,31 \mathrm{~kW}$ güç ve $1 \mathrm{~m} / \mathrm{dk}$ hız ile elde edilmiştir. 
Deneysel çalışmalardan görülmektedir ki lazer ışınının gücü, kaynak dikişi, mikroyapı ve mekanik özellikler üzerinde büyük öneme sahiptir. Farklı malzemeler ve farklı kalınlıklar için gerekli güç değeri değişkenlik göstermektedir. Kalın parçalarda tam nüfuziyet için daha yüksek güç değerleri seçilmelidir. Bu güç seçilirken dikkat edilmelidir. Aşırı yüksek güç seçimi malzemelere zarar verecek, mekanik özelliklerde düşüşe neden olacaktır. Dar ITAB ve EB, lazer kaynağının en önemli avantajlarından olup, malzemede çarpılmaların minimum olmasını sağladığı görülmüştür.

\subsection{Kaynak İlerleme Hızı}

Kaynak esnasında lazer ışınının malzemeler üzerinde ilerleme hızı oldukça önemlidir. Hız, 1S1 girdisini doğrudan etkilemektedir. Yapılan çalışmalar göstermektedir ki artan kaynak hızı 1sı girdisini azaltır, içyapı ve mekanik özellikleri etkiler. Kaynak ilerleme hızının malzeme kalınlığı ve cinsine göre güç değeriyle ideal kombinasyonu sonucu tatmin edici sonuçlar literatürde mevcuttur.

Fernandes ve diğ. (2017) DP600 çeliklerini kaynak etmiş ve tam birleşme durumunda malzeme alt yüzeyinde karanlık bir bölgenin varlığını görmüş ve kaynak hızını 0,48 m/dk'dan $3,84 \mathrm{~m} / \mathrm{dk}$ değerine düşürerek bu sorunu çözmüşlerdir. Xia ve diğ. (2008) DP450, DP600 ve DP980 çeliklerini lazer ile kaynak etmiş, 1sı girdisini kaynak hızını değiştirerek değiştirmişlerdir. Çok yüksek kaynak hızlarında ITAB'da sertlikte az düşüş gözlenirken, tersi olarak düşük hızda sertlik düşüşü daha ciddidir. Aynı zamanda kaynak hızı artışı ile ITAB'ın genişliği ve derinliği azaldığı gösterilmiştir. Jia ve diğ. (2016) DP980 çelikleri ile gerçekleştirdiği çalışmada $1 \mathrm{~m} / \mathrm{dk}$ ve $4 \mathrm{~m} / \mathrm{dk}$ hızlarda kaynak işlemi gerçekleştirmiş, çekme dayanımlarını, düşük hız için (yüksek ısı girdisi) TM'nin \%95,6'sı ve yüksek hız (düşük 1sı girdisi) için \%99,7'si olarak bulmuşlardır. Yüksek 1s1 girdisinin ITAB'da dayanımda düşmeye neden olduğunu bildirilmiş̧ir. Çekme deneyinde yüksek hızda gerçekleştirilen kaynak işleminde kopma TM'de olurken düşük hızda kopma TM tarafı ITAB'da gerçekleşmiştir. ITAB genişliği ve yumuşama derecesi arttıkça çekme dayanımlarında düşüş olduğu ifade edilmiştir. Xia ve diğ. (2008) silisyum alaşımlı TRIP ve alüminyum alaşımlı TRIP çelikleri ile yaptıkları lazer kaynak çalışmasında, $4 \mathrm{~kW}$ diyot lazer ile alın kaynak işlemi gerçekleştirmişlerdir. 1,2-2,2 m/dk kaynak hızlarıyla çalışmışlardır. İki çeliğin de TM sertlikleri benzerdir (220-250 HV). Ancak kaynak işlemi sonrası silisyum alaşımlı TRIP çeliğinde EB'de 494 HV'ye varan sertlikler mevcutken, alüminyum alaşımlı çelikte ise EB'de 349 HV maksimum sertlikler mevcuttur ve bu değerler iki çelik için de $2 \mathrm{~m} / \mathrm{dk}$ hızda görülmüştür. Silisyum alaşımlı TRIP TM'sinin, mukavemet ve uzama değerleri açısından daha başarılı olduğu görülmüştür. Ancak kaynak sonrası silisyum alaşımlı TRIP EB'si dayanım ve süneklikte ciddi bir düşüş göstermiştir. Wang ve diğ. (2016) yaptıkları çalışmada 1,5 mm kalınlığında DP1000 çeliğini 1,3 kW sabit güç lazer ile kaynak etmiş, 1s1 girdisini kaynak hızını değiştirerek kontrol etmiş̧lerdir. 0,24-0,84 $\mathrm{m} / \mathrm{dk}$ aralığında gerçekleştirilen deneylerde 1sı girdisinin azalmasıyla EB ve ITAB'da daralma ve mekanik özelliklerde iyileşme görülmüştür. Jia ve diğ. (2018) 1,36 mm kalınlığında QP980 ve 1,2 mm kalınlığında B1500HS çeliklerini 4,5 kW güç ve 4-10 m/dk hızlarda, $300 \mathrm{~mm}$ odak mesafesi, $0.3 \mathrm{~mm}$ fiber çapı ve $0,6 \mathrm{~mm}$ 1şın çapı kullanarak fiber lazer ile alın kaynağ 1 işlemi gerçekleştirmiş, içyapı özelliklerini incelemişlerdir. 4-8 m/dk hızlarda tam birleşme sağlanırken $10 \mathrm{~m} / \mathrm{dk}$ hızda tam birleşme sağlanamamıştır. ITAB'ın yumuşamış bölgelerinde TM'ye göre QP980 çeliğinde 15 HV düşüş gözlenirken, B1500HS çeliğinde 187 HV düşüş gözlenmiştir. 4 $\mathrm{m} / \mathrm{dk}$ hızında maksimum akma ve maksimum çekme değerleri görülmüş, birleşmenin en zayıf noktası B1500HS'nin ITAB'ının yumuşamış bölgesi olduğu ifade edilmiştir. Erichsen çökertme 
deneyinde de çatlak başlangıcının B1500HS'nin ITAB'ının yumaşamış bölgesinde olduğu belirtilmiştir. Palanivel ve diğ. (2020) HSLA çeliklerini Nd:YAG ile 1,5-3,5 m/dk hız aralığındaki değerlerde kaynak etmiş, kaynak hızının artmasıyla EB genişliğinin azaldığını görmüşlerdir. 1,5 m/dk kaynak hızında $367 \mathrm{MPa}$ çekme mukavemeti görülürken 3,5 m/dk hızında $567 \mathrm{MPa}$ çekme mukavemeti elde edilmiş ve yüksek hızda gerçekleştirilen işlemde çekme mukavemeti değerinin ana metalin çekme mukavemeti değerinin \%97'sine karşılık geldiği bulunmuştur. Uzun ve Keleş (2012) AISI 304 çelikleri ile yaptığ çalışmada kaynak ergime bölgesinin ve geçiş bölgesinin artan kaynak hızıyla azaldığını göstermişlerdir. 0,1-0,4 $\mathrm{m} / \mathrm{dk}$ ile yaptıkları çalışmada $1 \mathrm{~kW}$ güç için tüm hızlarda tam birleşme sağlanırken artan kaynak hızı ergime bölgesini daraltmıştır. Mikrosertlik değerleri incelendiğinde kaynak hızındaki artış sertlik değerlerinin düşmesine neden olmuştur. Köse ve Kaçar (2015) AISI 316L paslanmaz çeliklerinin lazerli kaynak birleştirmelerini mekanik ve mikroyapı özellikleri yönünden değerlendirmiş, $3,5 \mathrm{~kW}$ sabit lazer gücü ve 0,9-1,8-2,7 m/dk kaynak hızlarında $\% 50$ argon $\% 50$ helyum atmosferinde işlemi gerçekleştirmişlerdir. Artan kaynak hızı ile 1S1 girdisinin azaldığı gösterilmiş bu sebeple de ergime bölgesinde daralma olduğu belirtilmiştir. Numunelere uygulanan darbe testinde ise kaynak ilerleme hızı artışıla darbe dayanımının belirgin şekilde arttığı gözlenmiştir. Çekme testlerinde ise ilerleme hızındaki artışın çekme dayanımlarını az miktarda iyileştirdiği sonucuna varılmıştır. Ayrıca $1,8 \mathrm{~m} / \mathrm{dk}$ ve $2,7 \mathrm{~m} / \mathrm{dk}$ hızlarda daha düzgün sertlik profili elde edilmiştir. Çakmakkaya ve diğ. (2020) yaptıkları çalışmada farklı tür ST6222 ve DP600 saclarını lazer ile birleştirmiş, kaynak dikiş geometrisi ve nüfuziyete parametrelerin etkilerini araştırmışlardır. 2-3-4 m/dk hızlarda kaynak işlemi gerçekleştirilmiş, artan ilerleme hızının numuneyle temas süresini azalttığı, sonucunda nüfuziyeti azalttığı belirtilmiştir. İlerleme hızının azalması ile kaynak genişliğinin arttığı gözlenmiştir. Anawa ve Olabi (2008) ferritik/östenitik çeliklerin lazer ile bileştirilmesinde çekme dayanımlarının en iyi olduğu değeri kaynak parametrelerini değiştirerek incelemiş ve kaynak hızının çekme mukavemeti üzerinde önemli etkisinin olduğunu belirtmişlerdir. 0,5-1 m/dk hızlarında yapılan çalışmada en iyi çekme değerleri $0,5 \mathrm{~m} / \mathrm{dk}$ hızında görülmüş, kaynak ilerleme hızının artması ile sonuçların kötüleştiği gösterilmiştir. Gu ve diğ. (2012) UHSS çeliklerinin Nd:YAG lazer ile birleştirilmesini 3,6-7,8 $\mathrm{m} / \mathrm{dk}$ hız aralığında gerçekleştirmiş, çalışmada kaynak hızındaki artışın EB genişliğini azalttığını, $6 \mathrm{~m} / \mathrm{dk}$ aşan hızlarda ise tam birleşme sağlanmadığını göstermişlerdir. Çalışmada maksimum çekme ve uzama değerleri $5,4 \mathrm{~m} / \mathrm{dk}$ değerinde görülmüştür. $5,4 \mathrm{~m} / \mathrm{dk}$ altındaki hızlarda tam birleşme sağlanmıştır. Çekme deneyinde ise 3,6-5,4 m/dk hızlarda kopma ITAB' da gerçekleşirken, $6 \mathrm{~m} / \mathrm{dk}$ ve üzerinde birleşme eksikliği sebebiyle EB'den kopmuştur. Sebebi azalan 1 sı girdisine bağlı malzemelerin tam birleşememesidir.

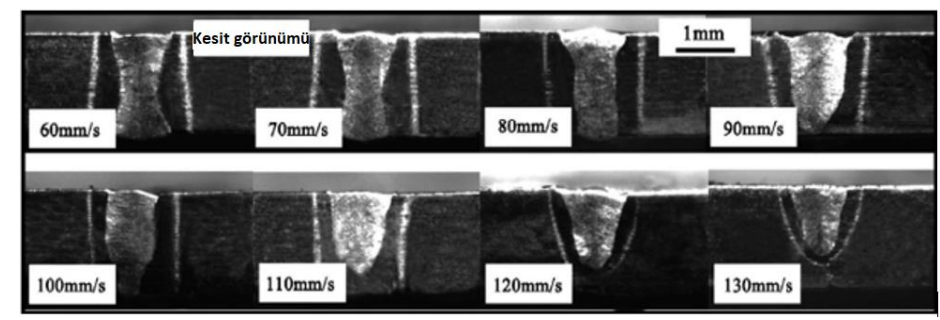

Şekil 3:

Artan kaynak ilerleme hızına göre birleşme kesitleri (Gu ve diğ.,2011) 
Salminen ve di g. (2016) 960QC çeliğinin lazer ile kaynak işleminde optik değişimler ve 1s1 girdisi değişimleri ile sonuçları incelemiş, düşük kaynak hızının yüksek 1sı girdisi anlamına geldiğini belirtmişlerdir. Düşük hızlarda daha geniş EB ve ITAB olduğunu göstermişlerdir. Çekme testlerinde kaynak hızının azalmasıyla dayanımın azaldığını belirtmiş, gerekçe olarak yumuşama derecesinin fazla olmasını göstermişlerdir.

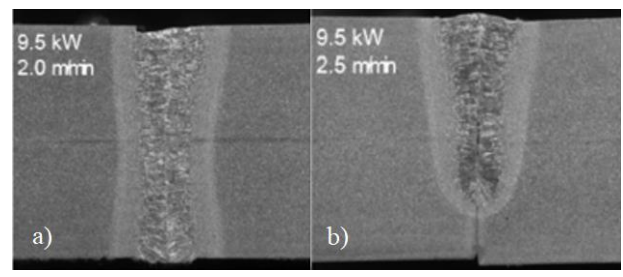

Şekil 4:

960QC için Aynı güç farklı hızda birleşme a) 2m/dk b) 2,5 m/dk (Salminen ve diğ.,2016)

Mevcut çalışmalar göstermektedir ki kaynak ilerleme hızı doğrudan 1sı girdisine etki etmekte, birleşme oranını ve iç yapıları etkilemektedir. Yüksek hız, malzemeye daha az zarar verir, maliyet ve zaman yönünden bize avantaj sunar. Hızın, olması gerekenden fazla seçilmesi durumunda tam birleşme sağlanamamaktadır. Bu da malzemede kullanım esnasında istenmeyen sonuçlar ortaya çıkarabilir. Düşük hız değerleri ise tam birleşme sağlarken malzemeye ITAB genişlemesi olarak etki etmekte, bu da mekanik özellikleri kötüleştirmektedir. Kaynak ilerleme hızı, kaynak edilecek malzeme türüne, kalınlığına ve lazer gücüne bağlı seçilmelidir. İdeal kombinasyon ile başarılı kaynak dikişleri ve mekanik özellikler elde etmek mümkündür.

\subsection{Lazer Türü}

Lazerler içlerinde çok farklı türlere ayrılır. Kullanılan aktif ortamın değişmesi çıkan ışının özelliklerini buna bağlı olarak değiştirir. Endüstride kaynak işleminde kullanılan lazerler, ışını verme özelliğine göre de sürekli 1şın (continuous wave) ve darbeli (pulsed) olarak değişmektedir. Sürekli ışın üreten ışın kaynağı için ana parametre güç iken darbeli modda çalışan lazerler için darbe frekansı, darbe süresi, ortalama güç gibi değerler ortaya çıkmaktadır. Darbeli mod için bu değişkenler kaynak kalitesine etki etmektedir.

Literatürde lazer ile malzemelerin birleştirilmesinde birçok çalışmada darbeli lazer kaynak makinesi kullanılmıştır. Darbeli lazerler belirli frekans değerinde atım gerçekleştirerek etki ettiği bölgeyi eritir ve birleşme sağlanır. Mevcut çalışmalar darbe süresini, darbe frekansını, ortalama güç ve tepe güç değerlerini değiştirerek uygun darbe parametrelerini bulmayı amaçlamaktadır.

Tunçel ve diğ. (2019) DP600 ve DP1000 çeliklerini Nd:YAG darbeli kaynak işlemi ile birleştirmiş ve darbe frekansının mekanik özellikler üzerine etkilerini incelemişlerdir. Yaptıkları çalışmada darbe frekansı hariç diğer veriler sabit tutulmuştur. 3-6,5 Hz frekans aralığında gerçekleştirdikleri çalışmada çekme dayanımının ve uzama değerlerinin frekansın artmasıyla arttığ 1 görülmüştür. $3 \mathrm{~Hz}$ değerinde çekme mukavemeti ve uzama yüzdesi sirasıyla $264 \mathrm{MPa}$ ve $\% 2,25$ iken, 6,5 Hz değerinde 610,5 Mpa ve \%20,45 değerleri elde edilmiştir. Daha yüksek darbe frekansının daha derin birleşme ve daha geniş EB ve ITAB'a yol açtığı görülmüştür. Bu çelik çiftinin lazer kaynağı için optimal parametreler $6,5 \mathrm{~Hz}$ darbe frekans1, 1,4 mm odak çap1, \%50 güç, 5 ms darbe süresi olarak verilmiştir. Hazretinezhad ve diğ. (2012) DP çelikleri 
üzerinde gerçekleştirdikleri çalışmada $12-15 \mathrm{~Hz}$ frekans ve $8-10 \mathrm{~ms}$ darbe süresi değerleriyle birleştirme işlemi gerçekleştirmiş, $15 \mathrm{~Hz}$ frekans ve $8 \mathrm{~ms}$ darbe süresi kombinasyonunda hem boyuna hem enine birleştirmede daha iyi sonuçlar elde etmişlerdir. İndhu ve diğ (2018) $2,5 \mathrm{~mm}$ kalınlığında DP600 çeliği ve 3 mm kalınlığında 6061 serisi alüminyumun bindirme kaynağı ile birleştirilmesinde 10-50-100 ms darbe sürelerinde deneyler gerçekleştirmiş, sabit güç için $50 \mathrm{~ms}$ ve $100 \mathrm{~ms}$ darbe sürelerinde kaynak kalınlığının arttığı ancak birleşme derinliğinin azaldığı sonucuna ulaşmışlardır. İdeal olarak $4 \mathrm{~kW}$ güç, $0,3 \mathrm{~m} / \mathrm{dk}$ kaynak hızı, $10 \mathrm{~ms}$ darbe süresinde $233 \mu \mathrm{m}$ birleşme derinliği ve $720 \mu \mathrm{m}$ birleşme genişliği bulmuşlardır. Behera (2020) $2 \mathrm{~mm}$ kalınlığında AISI 316L ve AISI 1552 çelikleri ile gerçekleştirdiği lazer kaynak işleminde, kaynak hızı, ışın çapı ve darbe frekansının, kaynak sertliği ve ITAB üzerine etkilerini incelemiş, Taguchi metoduyla parametreleri optimize etmiş ve atım frekansının diğer değişkenlere göre daha az önemde olduğunu belirtmiştir. Tunçel ve diğ. (2020b) $1 \mathrm{~mm}$ kalınlığında DP600 çeliklerini tek taraflı ve çift taraflı olarak kaynak etmiş, işlemlerde farklı darbe frekansı değerleri kullanmışlardır. Hem tek taraflı hem çift taraflı kaynak işlemlerinde 4,5-8,5 Hz aralığında yaptıkları çalışmada darbe frekansının artmasıyla çekme mukavemetinde ve uzama yüzdesinde artış görülmüştür. Çift taraflı birleştirmeler incelendiğinde $4,5 \mathrm{~Hz}$ için çekme mukavemeti değeri $234,5 \mathrm{MPa}$ ve uzama yüzdesi \%0,125 iken $8,5 \mathrm{~Hz}$ için bu değerler $611 \mathrm{MPa}$ ve \%10,06 olarak bulunmuştur. Bu değerler hem tek taraflı hem de çift taraflı birleştirmeler için neredeyse doğrusal olarak artarken $8,5 \mathrm{~Hz}$ üzerindeki değerler için inceleme yapılmamıştır. Tunçel ve diğ. (2018) bu çalışmada ise $1 \mathrm{~mm}$ kalınlıkta DP600 çeliklerinin lazer ile birleştirilmesinde darbe süresinin mikroyapı ve mekanik özelliklere etkisini incelemiş, yüksek darbe süresinde kaynak birleşme derinliğinin arttığını ve birleşme kusurlarının azaldığını göstermişlerdir. \%50 güç, $5 \mathrm{~Hz}$ darbe frekans1, 1,4 mm 1şın çapı ve 2-8 ms aralığında değişen darbe süresi ile gerçekleştirilen çalışmada en yüksek kaynak mukavemeti ve uzama değerlerinin 6,5 ms darbe süresinde olduğu gözlenmiştir. 2 ms'den 6,5 ms'e kadar değerler artarken, buradan sonra azalma görülmüştür. Yüksek darbe süreleri ile istenen kalitede kaynak kalitesinin yakalanabileceği belirtilmiştir. Xue ve diğ. (2017) DP1000 çeliğini darbeli Nd:YAG lazer ile birleştirmiş, \%20-86 güç, 0,3-23 ms darbe süresi, 0,6-2 mm 1şın çapı, farklı atım tipleri ve 0,06$1,62 \mathrm{~m} / \mathrm{dk}$ parametreleri ile parametrelerin birleşmeye ve mikroyapıya etkilerini incelemişlerdir. Yüksek darbe sürelerinin derin birleşmeye yol açtığı, atım tipinin birleşme üzerinde önemli etkisini olmadığı, kaynak hızının ise birleşmeye direk olarak etkilediği sonuçlarına ulaşmışlardır.

Literatürdeki çalışmalarda endüstride sıkça kullanılan darbeli lazer kaynağı ile malzemelerin birleştirilmesi işleminde darbe süresi ve darbe frekansı birleşme bölgesinin içyapısına, kaynak dikişine ve mekanik özelliklere etki ettiği gözlenmiştir. Genel olarak yüksek darbe frekansı ve yüksek darbe süreleri daha iyi birleşme sağlamış, ancak ITAB ve EB geniş̧liklerini de arttırdığı görülmüş̧ür. Hem tam birleşme sağlanan hem de minimum ITAB ve EB genişlik değerleri sunan frekans ve süre değerleri seçilmelidir.

\subsection{Odak Mesafesi, Işın Çapı, Odak Noktası}

Lazer ışınının kafadan çıkması sırasında malzemeye odaklanacağı nokta, ışının çapı ve odak mesafesinin, malzemelerin birleşme kalitesini etkilediği yapılan çalışmalardan görülmüştür. Lazer kafasında, kafaya kadar gelen ışını toplamak için toplayıcı (kollimatör) lens ve toplanan 1şı̆̆ı malzeme üzerinde istenen noktaya odaklamak için odak lensi kullanılmaktadır (Püskülcü ve Koçlular, 2009). Kullanımı yaygınlaşan fiber kablolar sayesinde lazer ışını daha kolay 
şekilde taşınmaktadır. Fiber kablodan gelen ışın sırasıyla toplayıcı lens ve odak lensine gelir, odaklanarak malzemeye iletilir. Şekil 5'te görüldüğü üzere kaynak edilecek malzemeye yakın olan lens, odak lensidir ve kaynak esnasında oluşacak sıçrama ve buhar bu lense zarar verebilir. $\mathrm{Bu}$ riski azaltmanın bir yolu odak mesafesi değerini olabildiğince uzak tutarak, kafanın malzemeden uzaklaşmasını sağlamaktır (Püskülcü ve Koçlular, 2009).

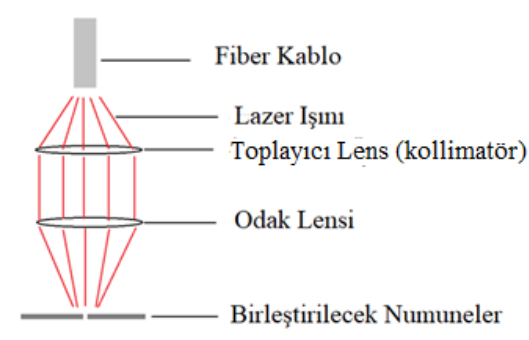

Şekil 5:

Odak ve Toplayıcı Lens

Odak noktası, lazer 1şınının malzemenin hangi noktasına odaklandığının bilgisini verir. Örnek olarak belirli kalınlıkta iki adet sac parça birleştirilirken, lazer ışınının parçaların üst yüzey, orta yüzey ya da alt yüzeyine odaklandığını anlatan ifadedir.

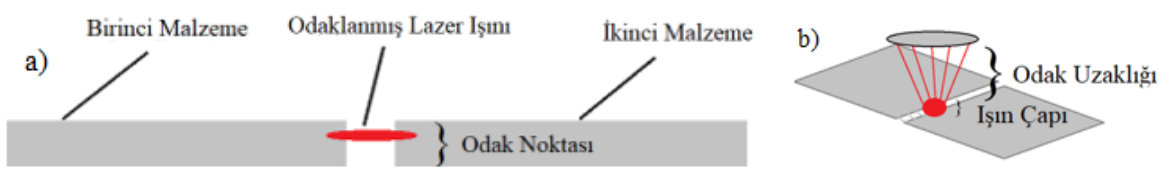

Şekil 6:

a) Lazer ış̧ııııın odak malzeme üzerindeki noktası ve b) Odak uzaklı̆̆ı ve ışıı çapı

Behera (2020) AISI 316L ve AISI 1552 çelikleri ile gerçekleştirdiği çalışmada Nd:YAG darbeli lazer kaynağı kullanmış, tarama hızı, ışın çapı ve darbe frekansı değerlerini değişsirmiş bu değerlerin kaynak sertliği ve ITAB özelliklerini nasıl etkilediğini incelemiştir. Taguchi metoduyla en uygun parametreleri bulmayı hedeflemiş ve ANOVA ile istatistiksel verileri elde etmiştir. Yaptığı çalışma sonucunda lazer 1şın çapının sertlik ve ITAB genişliği üzerinde en büyük etkiye sahip olduğunu belirtmiştir. İdeal parametreleri ise $0,3 \mathrm{~mm}$ atım çapı, $0,045 \mathrm{~m} / \mathrm{dk}$ ilerleme hızı ve $7 \mathrm{~Hz}$ darbe frekansında elde etmiştir. Benyounis ve diğ. (2008) AISI304 paslanmaz çeliğine lazer ile alın kaynă̆ uygulamışlardır. Çalışmada 1,5 kW maksimum çıkış gücünde sürekli mod $\mathrm{CO}_{2}$ lazer kullanılmıştır. Lazer kaynaklı bağlantının çekme dayanımı, darbe dayanımı ve bağlantı işletme maliyeti çıktı parametreleri olarak alınmıştır. Çıktı parametreleri ile ilişki kurmak için lazer gücü, odak noktası konumu ve kaynak hızı bu çalışmada girdi faktörleri olarak alınmıştır. Deneyler sonunda, kaynak hızının, $-0.2 \mathrm{~mm}$ odak noktasında 0,35 ila $0,39 \mathrm{~m} / \mathrm{dk}$ aralığında, $-0.8 \mathrm{~mm}$ odak değerinde $0,6 \mathrm{~m} / \mathrm{dk}$ olması gerektiği sonucuna varmışlardır. Lazer gücünün 1,2-1,23 kW aralığında ideal olduğunu belirtmişlerdir. Verilen uygulama için en uygun kaynak koşulları kullanılarak \%43 maliyet düşüşü elde edilebileceği ifade edilmiştir. Anawa ve Olabi (2008) 2 mm kalınlığındaki ferritik östenitik çelik 
numunelerin çekme mukavemetini iyileştirmek için bir optimizasyon çalışması gerçekleştirmiş, güç, ilerleme hızı ve odak noktasını değiştirmişlerdir. Sürekli modda $\mathrm{CO}_{2}$ lazeri ile gerçekleştirilen çalışmada odak noktası ve odak mesafesinin sonuçlar üzerinde önemli etkileri olmadığını belirtmişlerdir. Deneyde -1 ile $0 \quad \mathrm{~mm}$ aralığında değişen odak noktası kullanmışlardır. İdeal değerleri ise $1 \mathrm{~m} / \mathrm{dk}$ ilerleme hızı, 1,31 kW güç ve -0,67 odak noktasında elde etmişlerdir. Salminen ve diğg. (2016) $8 \mathrm{~mm}$ kalınlığında 960QC çeliğinin lazer ile kaynak edilmesinde optik parametrelerin kaynak kalitesi ve mekanik özellikler üzerine etkilerini incelemiş, $10 \mathrm{~kW}$ gücünde sürekli modda fiber lazer sistemi kullanmışlardır. Fiber kablo çapı $200 \mu \mathrm{m}$ ve $600 \mu \mathrm{m}$ kullanılmış, 1şın çapları sırasıyla $0,71 \mathrm{~mm}$ ve $1,46 \mathrm{~mm}$ ile çalışılmıştır. Odak noktası malzeme üst yüzeyinin $1 \mathrm{~mm}$ aşağısı olarak seçilmiştir. Farklı hızlarda bu değerler için kaynak işlemi gerçekleştirilmiştir. Düşük ışın çapında daha iyi nüfuziyet sağlandığı gösterilmiştir. Büyük çap ve yüksek hız kombinasyonunda ise tam birleşme sağlanamadığ görülmüştür. Düşük 1şın çapı için daha dar ITAB ve EB elde edilmiştir.

Yapılan çalışmalardan görülmektedir ki lazer 1şın çapı, odak uzaklığı ve odak noktası kolay kontrol edilebilir giriş parametreleridir ve değişimleri de birbiriyle bağlantılıdır. Aynı güç değeri için, 1şın çapı küçük olması daha dar ITAB ve EB sağlar, daha yüksek güç yoğunluğu sayesinde daha iyi birleşme gerçekleşir. Bu sayede daha yüksek kaynak hızları ve daha hızlı üretim mümkün olabilir. İnce malzemelerin birleştirilmesinde odak noktası daha az öneme sahipken kalın parçalar için lazer ışınının çapı ve odak noktası daha büyük önem kazanmaktadır. Örnek olarak 20 mm kalınlığında parçaları lazer ile birleştirmek için ışını üst yüzeye odaklamak tam birleşme için yeterli olmayabilir.

\section{Makroyapı, Mikroyapı ve Mekanik Özellikler}

Tüm kaynak işlemleri temelde, ergime, döküm ve katılaşma olarak açıklanabilir. Bu sistem oldukça hızlı gerçekleşir. Lazer kaynağında da durum benzer olmakla birlikte diğer yöntemlere göre odaklanmış 1şın sayesinde 1sı dar bir bölgeye nüfuz ettirilerek daha dar ergime bölgesi ve daha dar 1sı tesiri altında bölge sağlanır. ITAB, malzemenin mekanik özelliklerini kötüleştirir ve dar olması istenmektedir. Makro düzeyde incelendiğinde, lazer kaynağının dar alana nüfuziyeti ve yüksek güç yoğunluğu sayesinde daha dar ITAB ve EB sağlanmaktadır. Araştırmacılar birçok çalışmada kaynak sonrası iç yapıları temel olarak temel malzeme (TM), 1sı tesiri altındaki bölge (ITAB) ve ergime bölgesi (EB) olarak ayırmışlardır. ITAB kendi içinde de farklı özellikler sergilemektedir ve bazı çalışmalar bu bölgeyi; EB'ye yakın bölge için EB tarafı ITAB, temel malzemeye yakın bölge için TM tarafi ITAB ve bu iki bölge arası geçiş bölgesi için geçiş ITAB olarak isimlendirmektedir. Çekme deneylerinde genellikle kopmalar TM tarafı ITAB'dan gerçekleşmekte, bu bölge tehlike arz etmektedir. Mikroyapıda görülen fazlar ise kullanılan malzeme türüne göre değişiklik göstermektedir.

Kim ve diğ. (2010) $\mathrm{CO}_{2}$ lazer ile kaynaklanmış DP780 çelik bağlantının çekme testi sırasında TM'de başarısız olduğunu belirtmişlerdir. Qiu ve Chen (2007) DP çelik bağlantılarında, temperlenmiş martenzit nedeniyle TM tarafı ITAB'ın TM'den daha düşük bir sertlikte olduğunu belirtmişlerdir. Di ve diğ. (2017) $1,5 \mathrm{~mm}$ kalınlıkta DP780 ve DP980 çeliklerini, $5 \mathrm{~m} / \mathrm{dk}$ hız, $2 \mathrm{~kW}$ güç, $0,3 \mathrm{~mm}$ 1şın çapı ve saf argon koruyucu gazı kullanarak fiber lazer kaynak işlemi gerçekleştirmiş, dayanım, şekillendirilebilme gibi özellikleri incelemişlerdir. EB sertlikleri DP980-DP980 birleşmesinde 386 HV, DP780-DP780 birleşmesinde $357 \mathrm{HV}$, DP780-DP980 birleşmesinde ise $375 \mathrm{HV}$ olarak belirtilmiştir. Çekme 
deneyinde kopmalar TM'de gerçekleşmiş, farklı malzemelerin birleşmesinde değerler, mukavemeti düşük olan DP780'e yakın çıktığı belirtilmiştir. Şekillendirme açısından ise Erichsen çökertme deneyi sonucu farklı malzemelerin birleşmesinde şekillendirilebilirliğin daha kötü olduğu belirtilmiş, sebebi asimetrik deformasyona ve farklı yumuşama derecelerine bağlanmıştır. Çatlağın DP780'in yumuşamış bölgesinden başladığı ve EB'ye paralel olarak ilerlediği belirtilmiştir. Palanivel ve diğ. (2020) HSLA çelikleri ile yaptığı çalışmada birleşme bölgesinde üç bölgenin varlığını göstermişlerdir. Bunlar TM, ITAB ve EB'dir. Bu üç bölgenin iç yapısının elektron mikroskobu görüntüsü Şekil 7'de verilmiştir. Ergime bölgesinin sert martenzitik yapıda olduğu belirtilmiştir.

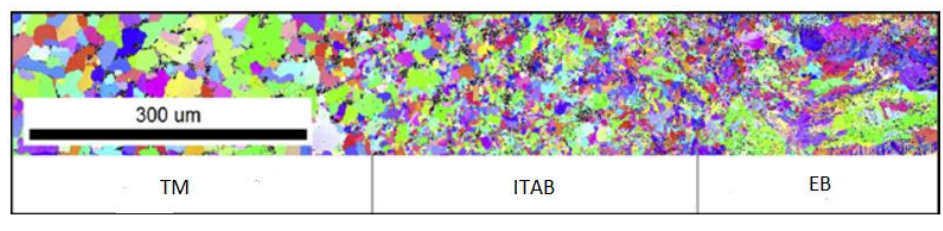

Şekil 7:

$T M$, ITAB ve EB (Palanivel ve di ̈., ,2020)

Li ve diğ. (2018) QP980 çeliğinin lazerle kaynak işlemini, 4,5 kW güç, $5 \mathrm{~m} / \mathrm{dk}$ hız, $30 \mathrm{~cm}$ odak mesafesi, 0,6 mm ışın çapı ve koruyucu gaz olmadan gerçekleştirmişlerdir. 1,36 mm kalınlığında numuneler kullanılmış olup, maksimum gücü $6 \mathrm{~kW}$ olan fiber lazer sistemi kullanılmıştır. Mikroyapı incelemeleri gerçekleştirilmiş, çekme ve Erichsen çökertme testleri sonucu mekanik özellikler ve şekillendirilebilirlik incelenmiştir. EB'de TM'ye göre ciddi oranda sertlik artışı gözlenmiştir (TM 365 HV, EB 499 HV). Maksimum sertlik EB tarafı ITAB'da (518 HV) görülmüştür. Çekme testlerinde kopmalar kaynak çizgisinden 7,8 mm uzaklıkta gerçekleşmiştir. Uzama değerleri ise TM \%26,64 iken, kaynak sonrası \%19,45'e düştüğü belirtilmiştir. Jia ve diğ. (2016) DP600 ve DP980 çelikleri ile gerçekleştirdiği çalışmada iki malzeme için de EB, ITAB, TM gözlemlerken, ITAB'ın EB tarafi, geçiş ve TM tarafı bölgeden meydana geldiğini göstermişlerdir. Yapıda iki malzeme için de yumuşak ITAB ve sert EB olduğu gözlenmiş, EB'deki sertliğin martenzitten oluşmasına, ITAB'daki yumuşamanın ise bu bölgedeki temperlenmiş martenzitin varlığına atfedilmiştir. EB birleşme hattı boyunca en yüksek sertlik değerlerini verirken, DP980 tarafı ITAB'da en ciddi yumuşama görülmüştür. Bu yumuşama DP600 tarafinda oldukça küçüktür. Çalışmada çekme deneylerinde kopmalar TM'den gerçekleşmiştir. 

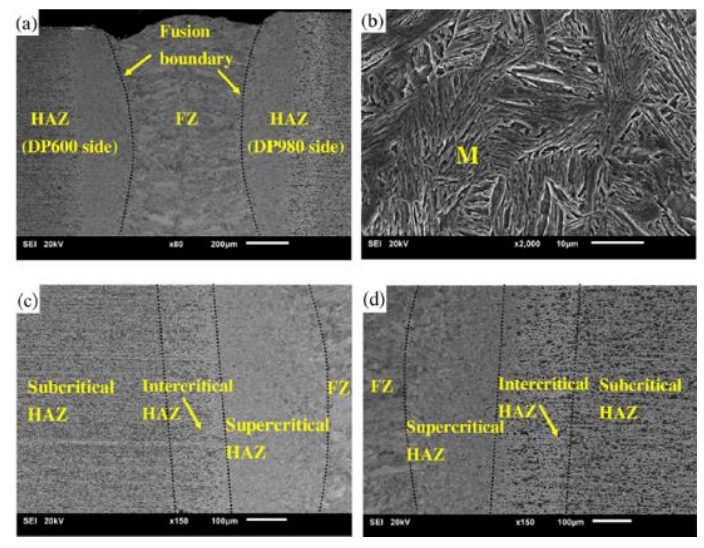

Sekil 8:

DP600 ve DP980 kaynak bölgesinde yapılar a) genel görünüm b) EB c) DP600 tarafi ITAB d) DP980 tarafi ITAB (Jia ve dĭg.,2016)

Guo ve diğ. (2018) QP980 çeliğini fiber kaynak ile birleştirmiş ve iç yap1 özellikleri incelenmişlerdir. TM, EB, EB tarafı ITAB, geçiş ITAB ve TM tarafı ITAB bölgelerinin varlığını göstermişlerdir. EB'nin martenzit, $\mathrm{EB}$ tarafı ITAB'ın martenzit, geçiş ITAB'ın martenzit, TM tarafi ITAB'ın temperlenmiş martenzit, ferrit ve kalıntı östenitten oluştuğu gözlenmiştir. En yüksek sertlik EB'de görülmüştür ve sebebinin martenzit yapısı olduğu belirtilmiştir. Tunçel ve diğ. (2020a) DP600 ve DP1000 çelikleri ile gerçekleştirdiği çalışmada EB'de martenzit, kalıntı östenit ve beynit olduğunu göstermişlerdir. ITAB'ın martenzit, beynit, ferrit, kalıntı östenit ve temperlenmiş martenzitten oluştuğunu görmüşlerdir. DP600-DP600 çelik çifti kaynağının çekme mukavemeti ana metalin \%97'si olarak görülürken, DP1000DP1000 birleşmesinde mukavemet değeri TM'nin \%86's1 olarak bulunmuştur. DP1000-DP1000 çiftinde mukavemet değerinin daha düşük çıkma sebebi büyük oranda bulunan sert martenzitik yapı olarak gösterilmiştir. Farklı malzeme çifti için kaynaklı numunelerin çekme mukavemeti değeri, çekme dayanımı düşük olan metale (çalışma için DP600) yakın çıkmıştır. En yüksek sertlik değerleri EB'de görülmüş ve sertliğin sebebinin martenzitik yapı olduğu belirtilmiştir. Dong ve diğ. (2014) DP600 çeliklerini lazer kaynak birleşmesinde ITAB'1 iç ITAB ve dış ITAB şeklinde iki bölgeye ayırmışlardır. EB'ye yakın kısım iç ITAB, TM'ye yakın kısım ise dış ITAB olarak gösterilmiştir. TM ferrit ve martenzitten oluşurken, EB tamamen martenzitik yapıdadır. İç ITAB'da martenzit ve ferrit mevcut ancak TM'ye göre martenzit oranı daha fazladır. Dış ITAB'da ise temperlenmiş martenzit mevcuttur. Dış ITAB'da sertlik değerlerinin en düşük olduğu görülmüş, bu bölgelere yumuşamış bölge ismi verilmiştir. Çekme testlerinde kopmalar iç ITAB'da meydana gelmiştir. Burada lokal sertleşme mevcuttur. Alves ve di ̌̆. (2018) DP1000 çelikleriyle gerçekleştirdiği lazer kaynak işleminde kaynak iç yapılarını martenzit, ferritten oluştuğunu göstermişlerdir. Kalıntı östenitin tüm kaynak bölgelerinde olduğu belirtilmiştir. ITAB'da geçiş ve TM tarafı bölgede yumuşama, kalıntı östenit ve birincil martenzitin temperlenmesiyle açıklanmaktadır. EB'den ITAB'a doğru gidildikçe kalıntı östenitin boyutu ve hacimsel oranının arttığı gözlenmiştir. Xu ve diğ. (2012) DP980 çelikleri ile yaptığı çalışmada fiber lazer ve diyot lazer kullanmış, fiber lazerde çok daha dar ITAB ve EB olduğunu bulmuşlardır. İki lazer kaynağında da dış ITAB'da temperlenmiş martenzite rastlanmıştır ve yumuşamanın sebebi olarak gösterilmiştir. Yüksek 1sı girdisi sebebiyle diyot lazer ile gerçekleştirilen kaynakta ITAB'da daha fazla temperlenmiş martenzit olduğu bulunmuştur. 
Diyot lazer ile gerçekleştirilen işlemde EB'de martenzit, beynit ve ferrit varken, fiber lazer ile gerçekleştirilen çalışmada EB'nin neredeyse tamamen martenzitik yapıda olduğu gösterilmiş, bu durumum nedeni hızlı soğuma olarak açıklanmıştır. Farabi ve diğ. (2011) DP600-DP980 çelikleri ile gerçekleştirdiği çalışmada EB'nin neredeyse tamamının martenzitten oluştuğu sonucuna ulaşmışlardır. Kaynak sonrası maksimum sertlik EB'de görülmüş, ITAB'da ise ani sertlik düşüşü gözlenmiş, TM'den daha az sertlik görülmüştür. Bu yumuşama martenzitin temperlenmiş martenzite dönüşümüne atfedilmiştir. Sertlik düşüşleri DP980'de daha ciddidir. Bu durumun nedeni ise DP980 çeliğinin TM'in daha yüksek oranda martenzit ihtiva etmesi ve yüksek oranda temperlenmiş martenzit oluşumudur. Çekme testlerinde kopmalar DP600 ITAB'da gerçekleşmiştir. Bu bölgede minimum sertlik mevcuttur. Kırılma yüzeyi incelemelerine göre kopma sünek olarak gerçekleşmiştir. Dong ve diğ. (2016) DP780 ve DP980 çeliklerini lazer kaynak ile birleştirmiş ve birleşme incelemelerinde makroyapıyı EB, ITAB'da önceki çalışmalarda görülen üç bölge ve TM olarak bulmuşlardır. EB, EB tarafı ITAB ve geçiş ITAB'da sertleşme gözlenirken, TM tarafi ITAB'da yumuşama gözlenmiştir. İki numunede de EB tarafı ITAB yapısı tamamen martenzit iken geçiş ITAB'ın martenzit ve ferritten oluştuğu gözlenmiştir. Kaynak merkezinden uzaklaşıldıkça ferrit oranı artmakta martenzit oranı azalmakta, sonucunda sertlik azalmaktadır. TM tarafı ITAB'ın ise temperlenmiş martenzitten oluştuğu gözlenmiştir ki bu yumuşamanın sebebi olarak belirtilmiştir. En düşük sertlik değeri DP780 TM tarafı ITAB'da görülürken, en büyük sertlik düşüşü DP980 TM tarafı ITAB'da gözlenmiştir. Huan ve diğ. (2019), DP çeliklerinde martenzit oranının mekanik özelliklere ve uzama değerlerine etkisini incelemiş, 1,5 mm kalınlığında DP590, DP780 ve DP980 çeliklerini kullanmışlardır. Tüm EB'lerde martenzite bağlı olarak sertliğin TM'ye göre 1,2-1,9 katı olduğunu belirtmişlerdir. Çekme deneylerinde tüm numunelerin TM'den koptuğu, ancak uzama değerlerinin TM’ye göre DP590 için, \%21,8 azaldığ1 ve martenzit oranının \% \%,4 arttı̆̆ belirtilmiştir. Erichsen çökertme deneylerinde, kaynaklı numunelerde TM'nin \%81,1'i ile \%91,7'si arası dayanım değerleri bulunmuştur. Saha ve diğ. (2014) $1.2 \mathrm{~mm}$ kalınlığında DP ve HSLA çeliklerine alın kaynağı işlemi gerçekleştirmişlerdir. DP çeliğinin EB'si tamamen martenzitik yapıda iken HSLA çeliğinin EB'sinin martenzit ve beynit içerdiği belirtilmiştir. DP980 TM tarafı ITAB temperlenmiş martenzit ve ferritten oluşmaktadır. Geçiş ITAB'da hızlı soğuma sonucu oluşmuş martenzit ve ferrit tanecik sınırlarında veya ferrit martenzit arayüzünde östenite rastlanmaktadır. HSLA çeliğinde ise TM tarafı ITAB gözlenmemiştir, sebebi daha stabil soğuma davranışı olarak açıklanmıştır. EB ve ITAB genişliklerinin işlem parametrelerine bağlı olduğu belirtilmiştir. DP980-DP980 çeliğinin kaynağında çekme mukavemeti değerleri kaynak hızının artmasıyla azalmış ve kopmalar TM tarafı ITAB'dan gerçekleşmiştir. HSLA çelik çifti kaynağında ise kaynak hızı artışı çekme dayanımlarını etkilememiş ayrıca kopmalar kaynaktan uzak bölgede TM'de gerçekleşmiştir. DP-HSLA çiftinde ise kopma HSLA tarafinda gerçekleşmiştir. Buradan DP980'in TM tarafı ITAB'ının HSLA TM'sinden daha yüksek mukavemetli olduğu anlaşılmaktadır. Gong ve diğ. (2016) $1,2 \mathrm{~mm}$ kalınlığında DP780 ve DP1180 çeliklerinin lazer kaynak ile birleştirilmesini incelemiş, çekme testine tabi tutmuşlardır. Kopmalar DP780 ITAB'ından gerçekleşmiştir. Jia ve diğ. (2016) DP980 çeliklerini lazer ile birleştirmiş, ITAB'1 dört bölgeye ayırmışlar, EB'den TM'ye doğru içyapıyı, iri taneli ITAB, ince taneli ITAB, geçiş ITAB ve TM tarafı ITAB olarak belirtmişlerdir. İnce taneli ITAB'in en yüksek akma ve çekme dayanımı gösterdiğini, geçiş ITAB'ın en kötü akma değerini, en düşük çekme değerinin ise TM tarafi ITAB'da meydana geldiğini belirtmişlerdir. ITAB genişliğinin fazla olmasının çekme dayanımı üzerinde negatif etkileri olduğu bildirilmiştir. Wang ve diğ. 
(2016) DP1000 çeliklerini lazer ile birleştirmiş ve çekme dayanımlarını ana metalin \%86-\%91'i aralığında bulmuşlardır. Kaynak sonrası TM'ye göre süneklik önemli ölçüde azalmış, uzama değerleri $\% 60$ civarında azalmıştır. ITAB'da yumuşama TM tarafı ve geçişte görülürken, yumuşamış bölgede sertlik TM'nin \%75'i, ITAB'daki sertleşmiş bölge olan EB tarafi ITAB'da ise sertlik TM'nin \%125'idir.

\section{KAYNAK ÖNCESİ VE SONRASI ISIL İŞLEM UYGULANMASI}

Deneysel çalışmalar kaynak işlemlerinde 1 sıl işlem uygulamanın iç gerilmeleri düşüreceğini, malzemeye verilen hasarı azaltacağını göstermektedir. Çalışmalarda, kaynak esnasında ya da kaynak sonrasında numuneler 1sıl işleme tabi tutulmuş, mikroyapı, makroyapı ve mekanik özellikler oda sıcaklığında gerçekleştirilen deneylerle kıyaslanmıştır.

Fernandes ve diğ. (2017) DP600 çelikleri ile gerçekleştirdikleri lazer ile birleştirme işleminde kaynak sonrası düzensiz sertlik oluşumunu gidermek, malzemenin tümünde sertlik değerlerinin yakın olmasını sağlamak amacıyla kaynak sonrası numuneleri iki farklı isıl işleme tabi tutmuşlardır. İlkinde $400^{\circ} \mathrm{C}$ 'de 2 saat bekletilip oda sıcaklığında soğumaya bırakılmış, ikinci 1 sıl işlemde ise $400^{\circ} \mathrm{C}$ 'de 4 saat bekletilip oda sicaklığında soğumaya bırakılmıştır. Isıl işlem uygulanan numunelerde uygulanmayan numunelere göre sertlikte düşmeler gözlenmiş ve daha düzgün bir sertlik profili elde edilmiştir. 2 saat ve 4 saat bekletme arasında ise çok büyük sertlik farkları gözlenmemiştir. Elastisite modülüne bakıldığında ise ilk ısıl işlemde 218-250 $\mathrm{GPa}$ değerleri gözlenirken, ikinci 1sıl işlemde 90-215 GPa değerleri gözlenmektedir. $\mathrm{Bu}$ da kaynak sonrası uygulanacak ısıl işlemin birleştirme üzerinde önemli etkisinin olduğunu göstermektedir. Ferreira ve diğ. (2020) DP980 çeliklerinin lazer ile birleştirilmesinde kaynak sırasında ve sonrasında ısıl işlem uygulayarak martenzit oluşumunu önlemeye çalışmışlardır. $527^{\circ} \mathrm{C}$ için TM'ye yakın sertlikler elde edilmiş ve düzgün bir 1sı dağılımı bulunmuştur. Oda sıcaklığında, 1sıl işlem uygulanmadan gerçekleştirilen birleştirmede 320-500 HV sertlikler ölçülürken, 1sıl işlem uygulandığında TM, ITAB ve EB için 280-300 HV civarında sertlikler ölçülmüştür. Birleştirme işleminde kalıntı gerilme değerleri oda sıcaklığında EB ve ITAB için $360 \mathrm{MPa}$ ve $470 \mathrm{MPa}$ iken, 1sıl uygulama ile bu değerler $120 \mathrm{MPa}$ ve $140 \mathrm{MPa}$ olarak bulunmuş, gerilmelerin 1sıl işlem ile 1/3'üne düşürülebileceği gösterilmiştir.

Literatürde yüksek mukavemetli çeliklerin lazer ile birleştirilmesi işleminde 1sı1 işlem uygulamaları kısıtlıdır. Mevcut çalışmalar sınırlı sayıda malzeme ile yapılmıştır. Yapılan çalışmalarda kaynak esnasında ya da kaynak sonrasında 1sıl işlem uygulanmasıyla, EB ve ITAB'da sertlik profilinin daha düzgün hale geldiği gözlenmiştir. Bu da daha iyi mekanik özellikler anlamına gelmektedir.

\section{SONUÇ}

Literatürde yer alan yüksek mukavemetli çeliklerin lazer ile birleştirilmesi işleminde optimal işlem parametrelerini tayin etmek için uygulanan yöntemler bu çalışmada özetlenmiştir. Lazer ile birleştirme yöntemi birçok açıdan avantajlı bir işlemdir. Çalışmalar kendi içinde gruplanarak önemli sonuçlar vurgulanmıştır. Lazer yoğun bir ışın gücü sunduğu ve dar alana nüfuz ettiği için ana malzemenin 1sıdan etkilenen bölgesi diğer kaynak çeşitlerine göre daha dar olur. Bu sayede ana malzemede en az seviyede hasar ve çarpılma gözlenir. Özellikle otomotiv sanayi için gerekli yüksek mukavemetli parçalarda bu özellikler hayati öneme sahiptir. Yüksek 
mukavemetli çeliklerin lazer ile birleştirilmesinde çeşitli zorluklar mevcuttur. $\mathrm{Bu}$ nedenle yüksek mukavemetli çeliklerin lazer ile birleştirilmesine ilişkin çalışmaların son yıllarda hız kazandığı anlaşılmıştır. Bu çalışmalar ideal lazer gücü, kaynak ilerleme hızı, odak uzunluğu ve 1şın çapı, darbe süresi ve frekansı gibi parametreler üzerinde yapılan değişiklikler ile başarılı sonuçların elde edilebileceğini göstermektedir. Çoğu çalışma güç ve hız girdileriyle ilgilenmekte, malzeme üzerinde etkileri üzerinde durmaktadır. Odak özellikleri ve lens üzerine çalışmalar ise sınırlıdır. Benzer şekilde ısıl işlem uygulamanın kaynak sonrası malzemeler üzerine etkilerini araştıran çalışma sayısı da çok az sayıdadır. Gelecekte belirtilen alanlar üzerine daha fazla araştırma yapılabilir.

\section{ÇIKAR ÇATIŞMASI}

Yazarlar bilinen herhangi bir çıkar çatışması veya herhangi bir kurum/kuruluş ya da kişi ile çıkar bulunmadığını onaylamaktadırlar.

\section{YAZAR KATKISI}

Kadir Çavdar, çalışmanın kavramsal ve tasarım süreçlerinin belirlenmesi, analizi ve yönetimi, Tuncay Alpar ve Oktay Çelenk veri toplama, veri analizi ve yorumlama.

\section{TEŞEKKÜR}

Bu çalışma TÜBİTAK BİDEB (Türkiye Bilimsel ve Teknolojik Araştırma Kurumu Bilim İnsanı Destekleme Daire Başkanlığı) tarafindan, TÜBİTAK 2244 Sanayi Doktora Programı kapsamında desteklenmiştir (Proje No: 119C115). TÜBİTAK'a teşekkürlerimizi sunarız.

\section{KAYNAKLAR}

1. Agarwal,G., Gao, H., Amirthalingam, M., Hermans, M. (2018) Study of solidification cracking susceptibility during laser welding in an advanced high strength automotive steel, Metals, 2018, 8, 673; doi:10.3390/met8090673

2. Alves, P.H.O.M., Lima, M.S.F., Raabe, D., Sandim, H.R.Z. (2018) Laser beam welding of dual-phase DP1000 steel, Journal of Materials Processing Technology, 252 (2018) 498510, doi:10.1016/j.jmatprotec.2017.10.008

3. Anawa E.M., Olabi, A.G. (2008) Optimization of tensile strength of ferritic/austenitic laser welded components, Optics and Lasers in Engineering, 46 (2008) 571-577, doi:10.1016/j.optlaseng.2008.04.014

4. Behera, A. (2020) Optimization of process parameters in laser welding of dis-similar materials, Materials Today; Proceedings 33 (2020) 5765-5769, doi:10.1016/j.matpr.2020.07.148

5. Benyounis, K.Y., Olabi, A.G., Hashmi, M.S.J. (2008) Multi-response optimization of co2 laser-welding process of austenitic stainless steel, Optics and laser technology, 40, 2008, 76-87, doi:10.1016/j.optlastec.2007.03.009

6. Çakmakkaya, M., Çolak, F., Kara, R., Karaağaçlı, A. (2020) Lazer kaynak yöntemiyle birleştirilen otomotiv endüstrisinde kullanılan farklı tür çeliklerin kaynak dikiş geometrisi ve nüfuziyetine kaynak parametrelerinin etkisi, Journal of Materials and Mechatronics A, 1(1), 1-11. 
7. Di, H., Sun, Q., Wang, X., Li, J. (2017) Microstructure and properties in dissimilar/similar weld joints between DP780 and DP980 steels processed by fiber laser welding, Journal of Materials Science \& Technology, Volume 33, Issue 12, 1561-1571, doi:10.1016/j.jmst.2017.09.001

8. Dong, D., Liu, Y., Yang, Y., Li, J., Ma, M., Jiang, T. (2014) Microstructure and dynamic tensile behavior of DP600 dualphase steel joint by laser welding, Materials Science \& Engineering A, 594 (2014) 17-25, doi:10.1016/j.msea.2013.11.047

9. Dong, D., Liu, Y., Wang, L., Yang, Y., Jiang, D., Yang R., Zhang W. (2016) Microstructure and deformation behaviour of laser welded dissimilar dual phase steel joints, Science and Technology of Welding and Joining, 21:2, 75-82, doi:10.1179/1362171815Y.0000000067

10. Evin, E., Tomas, M. (2017) The influence of laser welding on the mechanical properties of dual phase and trip steels, Metals, 7, 239; doi:10.3390/met7070239

11. Farabi, N., Chen, D.L., Zhou, Y. (2011) Microstructure and mechanical properties of laser welded dissimilar DP600/DP980 dual-phase steel joints, Journal of Alloys and Compounds, 509 (2011) 982-989, doi:10.1016/j.jallcom.2010.08.158

12. Fernandes, F.A.O., Oliveira, D.F., Pereira, A.B. (2017) Optimal parameters for laser welding of advanced high-strength steels used in the automotive industry, Manufacturing Engineering Society International Conference 2017, MESIC 2017, 28-30 June 2017, Vigo (Pontevedra), Spain, Procedia Manufacturing, 219-226, doi:10.1016/j.promfg.2017.09.052

13. Ferreira, C.C.A., Braga, V., Siqueira, R.H.M., Carvalho, S.M.C., Lima, M.S.F (2020) Laser beam welding of DP980 dual phase steel at high temperatures, Optics and Laser Technology, 124 (2020) 105964, doi:10.1016/j.optlastec.2019.105964

14. Gong, H., Wang, S., Knysh, P., Korkolis, Y.P. (2016) Experimental investigation of the mechanical response of laser-welded dissimilar blanks from advanced- and ultra-highstrength steels, Materials and Design, 90 (2016) 1115-1123, doi:10.1016/j.matdes.2015.11.057

15. Gu, Z., Yu, S., Han, L., Xu, H. (2012) Influence of welding speed on microstructures and properties of ultra-high strength steel sheets in laser welding, ISIJ International, Vol. 52 (2012), No. 3, 483-487, doi:10.2355/isijinternational.52.483

16. Guo, W., Wan, Z., Peng, P., Jia, Q., Zou, G., Peng, Y. (2018) Microstructure and mechanical properties of fiber laser welded QP980 steel, Journal of Materials Processing Technology, 256 (2018) 229-238, doi:10.1016/j.jmatprotec.2018.02.015

17. Huan P., Wang, X., Yang, L., Zheng, Z., Hu, Z., Zhang, M., C., C. (2019) Effect of martensite content on failure behavior of laser welded dual-phase steel joints during deformation, Journal of Materials Engineering and Performance, Volume 28, Issue 3, pp.1801-1809, doi:10.1007/s11665-019-03941-3

18. Huetter, J. 2015. Audi: Aluminum helped cut 716.5 pounds out of 2017 Q7 on sale soon. Erişim Adresi: http://www.repairerdrivennews.com/2015/12/28/audi-aluminum-helped-cut716-5-pounds-out-of-2017-q7-on-sale-soon/ (Erişim Tarihi: 15.04.2021).

19. Herd, R.M., Dover, J.S., Arndt, K.A. (1997) Basic laser principles, Dermatologic Clinics, 15(3), 355-372, doi: 10.1016/s0733-8635(05)70446-0

20. Hazretinezhad, M., Arab, N.B.M., Sufizadeh, A.R., Torkamany, M.J. (2012) Mechanical and metallurgical properties of pulsed neodymium-doped yttrium aluminum garnet laser welding of dual phase steels, Materials and Design, 33 (2012) 83-87, doi:10.1016/j.matdes.2011.06.070 
21. Indhu, R., Divya, S., Tak, M., Soundarapandian, S. (2018) Microstructure development in Pulsed Laser Welding of Dual Phase Steel to Aluminium Alloy, Procedia Manufacturing, 26 (2018) 495-202, doi:10.1016/j.promfg.2018.07.058

22. Iordachescu, D., Blasco, M., Lopez, R., Cuesta, A., Iordachescu, M., Ocaña, J. L. 2011. Development of robotized laser welding applications for joining thin sheets, Proceedings of 2011 International Conference on Optimization of the Robots and Manipulators (Optirob), 26-28

23. Jia, Q., Guo, W., Li, W., Zhu, Y., Peng, P., Zou, G. (2016) Microstructure and tensile behavior of fiber laser-welded blanks of DP600 and DP980 steels, Journal of Material Processing Technology, 236(2016), 73-83, doi:10.1016/j.jmatprotec.2016.05.011

24. Jia, Q., Guo, W., Li, W., Peng, P., Zhu, Y., Peng, Y., Tian, Z. (2017) Experimental and numerical study on local mechanical properties and failure analysis of laser welded DP980 steels, Materials Science \& Engineering A, $680 \quad$ (2017) 378-387, doi:10.1016/j.msea.2016.10.121

25. Jia, Q., Guo, W., Wan, Z., Peng, Y., Zou, G., Tian, Z., Zhou, Y.N. (2018) Microstructure and mechanical properties of laser welded dissimilar joints between QP and boron alloyed martensitic steels, Journal of Materials Processing Tech., 259 (2018) 58-67, doi:10.1016/j.jmatprotec.2018.04.020

26. Khan, M.M.A., Romoli, L., Fiaschi, M., Dini, G., Sarri, F. (2011) Experimental design approach to the process parameter optimization for laser welding of martensitic stainless steels in a constrained overlap configuration, Optics and laser technology 43, 2011, 158172, doi:10.1016/j.optlastec.2010.06.006

27. Kim, C.H., Choi, J.K., Kang, M.J., Park, Y.D., 2010. A study on the co2 laser welding characteristics of high strength steel up to 1500 mpa for automotive application. Journal of Achievements in Materials and Manufacturing Engineering. 39, 79-786

28. Kim, H.J., Keoleian, G.A., Skerlos, S.J. (2010) Economic assessment of greenhouse gas emissions reduction by vehicle lightweighting using aluminum and high-strength steel, Journal of Industrial Ecology, 64-80, doi:10.1111/j.1530-9290.2010.00288.x

29. Kökey, C., Sezgin, S., Niyazi, Ç., İrizalp, S.G., Saklakoğlu, İ.E. (2016) İnce paslanmaz çelik sacların fiber lazer ile kaynak edilebilirliğinin incelenmesi, Mühendis ve Makina, 57(624), 65-72

30. Köse, C., Kaçar, R. (2015) Kaynak ilerleme hızının AISI 316L paslanmaz çelik lazer kaynaklı birleştirmelerinin mekanik ve mikroyapı özelliklerine etkisi, Gazi Üniversitesi Mühendislik Mimarlık Fakültesi Dergisi, 30(2), 225-235, doi:10.17341/gummfd.49344

31. Lakshminarayana P.V.S., Gautam, J.S., Mastanaiah, P., Reddy, G.M., Rao, K.B.S. (2018) Influence of beam power and traverse speed in fibre laser welding of dual phase steel (590) on depth of weld zone penetration, Microstructure and Hardness, Materials Today: Proceedings 5 (2018), 17132-17138, doi:10.1016/j.matpr.2018.04.121

32. Li, W., Ma, L., Peng, P., Jia, Q., Wan, Z., Zhu, Y., Guo, W. (2018) Microstructural evolution and deformation behavior of fiber laser welded QP980 steel joint, Materials Science \& Engineering A, 124-133, doi:10.1016/j.msea.2018.01.050

33. Öztürk, E., Arıkan, H., Toros, S., Kayrıcı, M. (2019) Co2 lazer yöntemi ile birleştirilmiş çift fazlı çeliklerin mekanik özelliklerinin belirlenmesi, Fourth International Iron and Steel Symposium (UDCS'19) 
34. Palanivel, R., Dinaharan, I., Laubscher, R.F. (2020) Microstructure and mechanical behavior of Nd:YAG laser beam welded high strength low alloy steel joints, International Journal for Light and Electron Optics, 208 (2020) 164050, doi:10.1016/j.ijleo.2019.164050

35. Püskülcü, G., Koçlular, F. (2009) Lazer kaynak yöntemi ve uygulamaları, Mühendis ve Makina, 50(599), 8-17

36. Qiu, X.G., Chen, W.L. (2007) The study on numerical simulation of the laser tailorwelded blanks stamping. J. Mater. Process. Technol. 187-188, 128-131 doi:10.1016/j.jmatprotec.2006.11.128

37. Rashid, M.S. (1981) Dual phase steels, Annual Reviews Material Science, (11), 245-266, doi:10.1146/annurev.ms.11.080181.001333

38. Rossini M., Russo, P. R., Cortese, L., Matteis, P., Firrao, D. (2015) Investigation on dissimilar laser welding of advanced high strength steel sheets for the automotive industry, Materials Science \& Engineering A, doi:10.1016/j.msea.2015.01.037

39. Saha D.C., Westerbaan, D., Nayak, S.S., Biro, E., Gerlich, A.P., Zhou, Y. (2014) Microstructure-properties correlation in fiber laser welding of dual-phase and HSLA steels, Materials Science \& Engineering A, 607 (2014), 445-453, doi:10.1016/j.msea.2014.04.034

40. Salminen, A., Farrokhi, F., Unt, A., Poutiainen, I. (2016) Effect of optical parameters on fiber laser welding of ultrahigh strength steels and weld mechanical properties at subzero temperatures, Journal of Laser Applications, 28, 022415 (2016), doi:10.2351/1.4943914

41. Saravanan, S., Sivagurumanikandan, N., Raghukandan, K. (2021) Effect of process parameters in microstructural and mechanical properties of Nd: YAG laser welded super duplex stainless steel, Materials Today: Proceedings, 39 (2021) 1248-1253, doi:10.1016/j.matpr.2020.04.101

42. Taşkın, M. Çalıgülü, U. (2009) AISI430/1010 Çelik çiftinin lazer kaynağında kaynak gücünün birleşmeye etkisi, Firat Üniversitesi Mühendislik Bilimleri Dergisi, 21(1), 11-22

43. Tunçel, O. Aydın, H., Çetin, Ş. (2021) Microstructure and mechanical properties of similar and dissimilar laser welds of DP600 and DP1000 steel sheets used in the automotive industry, Turkish Journal of Engineering, 2021, 5(1), 08-14, doi:10.31127/tuje.649975

44. Tunçel, O., Aydın, H. (2019) Tensile properties of pulsed Nd:YAG laser welded dissimilar DP600-DP1000 steel sheets, Alternative Energy Sources, Materials \& Technologies (AESMT'19), Volume 1, 111 - 112, 2019

45. Tunçel, O., Aydın, H., Çetin, Ş. (2020a) Microstructural and mechanical properties of nd:yag laser welded dissimilar DP600-DP1000 steel sheets, Afyon Kocatepe Üniversitesi Fen ve Mühendislik Bilimleri Dergisi, (2020) 015901 (155-164), doi:10.35414/akufemubid.620768

46. Tunçel, O., Aydın, H., (2020b) A Comparison of tensile properties of single-sided and double-sided laser welded DP600 steel sheets, Materials Science (Medžlagotyra), Vol. 26, No. 2. 2020, doi:10.5755/j01.ms.26.2.21374

47. Tunçel, O., Aydın, H., Çetin, Ş. (2018) Nd:Yag lazer kaynağı ile birleştirilen DP600 çeliğinde darbe süresinin mikroyapı ve mekanik özelliklerine etkisi, 9th International Automotive Technologies Congress, OTEKON 2018

48. Uzun, R.O., Keleş, Ö. (2012) Lazerle kaynak işleminde parametrelerin kaynak kalitesi üzerindeki etkilerinin incelenmesi, Gazi Üniversitesi Mühendislik Mimarlık Fakültesi Dergisi, 27(3), 509-517 
49. Wang C., Mi, G., Zhang, X. (2021) Welding stability and fatigue performance of laser welded low alloy high strength steel with $20 \mathrm{~mm}$ thickness, Optics and Laser Technology, 139 (2021) 106941, doi:10.1016/j.optlastec.2021.106941

50. Wang, X., Sun, Q., Zheng, Z., Di, H. (2017) Microstructure and fracture behavior of laser welded joints of DP steels with different heat inputs, Materials Science \& Engineering A, 699 (2017) 18-25, doi:10.1016/j.msea.2017.05.078

51. Wang, J., Yang, L., Sun, M., Liu, T., Li, H. (2016) Effect of energy input on the microstructure and properties of butt joints in DP1000 steel laser welding, Materials and Design, 90 (2016) 642-649, doi:10.1016/j.matdes.2015.11.006

52. Xia, M., Biro, E., Tian, Z., Zhou, Y.N. (2008) Effects of heat input and martensite on haz softening in laser welding of dual phase steels, ISIJ International, Vol. 48 (2008), No. 6, 809-814, doi:10.2355/isijinternational.48.809

53. Xia, M. Tian, Z., Zhao, L., Zhou, Y.N. (2008) Metallurgical and mechanical properties of fusion zones of trip steels in laser welding, ISIJ International, Vol. 48 (2008), No. 4, pp. 483-488, doi:10.2355/isijinternational.48.483

54. Xue, X., Pereira, A.B., Amorim, J., Liao, J. (2017) Effects of pulsed nd:yag laser welding parameters on penetration and microstructure characterization of a DP1000 steel butt joint, Metals, 2017, 7, 292; doi:10.3390/met7080292

55. Xu, W., Westerbaan, D., Nayak, S.S., Chen, D.L., Goodwin, F., Biro, E., Zhou, Y. (2012) Microstructure and fatigue performance of single and multiple linear fiber laser welded DP980 dual-phase steel, Materials Science and Engineering A, 553 (2012) 51- 58, doi:10.1016/j.msea.2012.05.091

56. Yüce, C., Tutar, M., Karpat, F., Yavuz, N. (2016) The optimization of process parameters and microstructural characterization of fiber laser welded dissimilar hsla and mart steel joints, Metals, 6, 245, doi:10.3390/met6100245 